\title{
Housing Price and Upgrading of Consumption Structure of Urban Residents in China
}

\author{
Zhihua Dai \\ College of Economics, Jinan University, Guangzhou, China \\ Email: onlydaizhihua@163.com
}

How to cite this paper: Dai, Z.H. (2019) Housing Price and Upgrading of Consumption Structure of Urban Residents in China. Modern Economy, 10, 156-174. https://doi.org/10.4236/me.2019.101011

Received: December 21, 2018

Accepted: January 11, 2019

Published: January 14, 2019

Copyright (C 2019 by author(s) and Scientific Research Publishing Inc. This work is licensed under the Creative Commons Attribution International License (CC BY 4.0).

http://creativecommons.org/licenses/by/4.0/

\begin{abstract}
This paper uses China Family Panel Studies of 2012 and 2014 year. The data examined the impact of rising housing prices on upgrading the consumption structure of urban residents. It turns out, in terms of the body, the rise in housing prices has inhibited the upgrading of the household consumption structure. For the family that rents commercial housing in the market, the rise has significantly inhibited the upgrading of the household consumption structure. The change of the proportion of high-level consumption structure to housing price is the most sensitive. For households with homes, if prices go up, the increase will significantly increase the share of households with multiple homes in the development and enjoyment of consumer spending, that is to say, multiple housing families have a greater wealth effect in the face of rising house prices. For households with one home, the wealth effect is not obvious, and the rise in house prices remains inhibitory effect, but not significant.
\end{abstract}

\section{Keywords}

Housing Price, Upgrading of Consumption Structure, CFPS

\section{Introduction}

After the "house reform" in 1998, with the development of the real estate market, China's housing prices continued to rise. The average selling price of commercial housing in the country rose from 2063 yuan per square meter in 1998 to 3800 yuan per square meter in 2008. As of 2017, this value continued to reach 7900 yuan/square meter. The average sales price of commercial housing in the country increased by 262\% between 1998 and 2017, while the average sales price of commercial housing in Beijing, Shanghai and other "first-tier cities" increased even more. At the same time, the Chinese economy has entered a new normal, 
and the traditional economic development mode that relies on investment and export lacks new impetus, stimulates domestic consumption, and promotes the upgrading of consumption structure as an inevitable choice for transforming the mode of economic development.

However, after entering the 21st century, the pace of upgrading the consumption structure is very slow. According to the data of the National Bureau of Statistics, from 2004 to 2013, the Engel's Coefficient ${ }^{1}$ of urban residents dropped from $37.66 \%$ to $35.0 \%$, only $2.66 \%$ in 10 years. At the same time, the proportion of urban development and enjoyable consumption expenditure increased from $33.48 \%$ to $34.10 \%$, and only $0.62 \%$ in 10 years, compared with developed countries. Compared with that, the upgrading of consumption structure is slow. On the other hand, as an important commodity and investment target, the rapid rise of housing prices will inevitably affect residents' consumption and savings' decision-making, and then affect the upgrading of consumption structure. Although many discussions have been made on the relationship between housing prices and residents' low consumption rate and high savings rate, few studies have been conducted on the relationship between housing prices and residents' consumption at the level of consumption structure upgrading. The relationship between house price and the upgrading of consumption structure needs further discussion.

Domestic research on household consumption structure is basically in its infancy. Most of the research on house price and consumption structure focuses on the macro field, mainly using liquidity constraints, preventive savings and other theories to do empirical research. In view of this, this paper chooses China Family Panel Studies (CFP2014, CFPS2012) to study the relationship between housing prices and the upgrading of household consumption structure of urban residents. The data are from the China Social Science Research Center of Peking University, so as to provide policy basis for formulating the correct housing price control policy and promoting the upgrading of consumption structure.

\section{Literature Review}

In theory, rising house prices will affect residents' consumption decisions. One view is that rising house prices restrain consumption [1]. In the upstream stage of the real estate market, rising house prices have become one of the important factors driving up the savings rate. When house prices continue to rise, people save for buying houses, save for repaying housing loans, and push up the savings rate [2]. Another view is that rising housing prices generally lead to an increase in the propensity of urban residents to consume [3]. Some studies even argue that the rise in housing prices cannot explain the rise in the savings rate of urban residents in China. On the contrary, there is a negative relationship between the savings rate of residents of different types of property rights and the rise in housing prices [4], from the point of view of the existing research, the conclu-

${ }^{1}$ Engel's Coefficient is the proportion of total food expenditure to total personal consumption expenditure. 
sions are not uniform. However, after reviewing the relevant literature of domestic and foreign scholars, it is found that the literature on the impact of housing prices on consumption is roughly based on three kinds of impact mechanisms: wealth effect, liquidity constraint effect and substitution effect.

"Wealth effect" is the most commonly used theory to study the impact of housing prices on consumption. As an important part of household wealth, housing assets will inevitably lead to the increase of household wealth, and the increase of wealth will stimulate more consumption [5]. Ludwig and Slok differentiate wealth effects into "convertible wealth effects" and "non-convertible wealth effects". Convertible wealth effects refer to the increase of household current income and household consumption expenditure caused by rising house prices for households with rental, sale or bank mortgage. The non-convertible wealth effect refers to the fact that although rising house prices have caused the increase of household housing assets, households have not taken such actions as house transaction, transfer and rental, which has not resulted in the increase of current income, but expect more household wealth in the future, and this expected increase in income will also increase household consumption expenditure. Gan [6] research shows that real estate wealth has a significant pulling effect on household consumption. Case, Shiller and Quigley use data from various states and countries in the United States to make empirical analysis and find that when housing prices rise, there will be a significant wealth effect. Benjamin et al. [7] used macro data to empirically analyze the relationship between house price and consumption. The empirical results show that house price and consumption are positively correlated, and the wealth effect of house price rise on consumption far exceeds the wealth effect of stock rise. When lending constraints loosen and house prices rise, some households will increase current consumption through mortgage loans and house sales [8] [9]. But Chen Jian and others [10] believe that China's credit constraints can not exert the wealth effect of housing.

Using micro-data, we can analyze the heterogeneous effect of housing prices on consumption. As far as wealth effect is concerned, Campbell and Coco [11] found that wealth effect is very obvious in the elderly who have a house, but it has little effect on the young people who rent a house. But Skinner [12] and Lehnert [13] concluded that the wealth effect is equally significant among young people, and that younger generations are more willing to borrow and cash in the face of rising house prices than older people.

From the above analysis, we will find that wealth effect is directed at households with housing. For rental households, rising house prices may bring about a "flow constraint effect", which is because for households who have not yet owned housing, when rising house prices, these households are more likely to save for buying houses, thus reducing current consumption. That is, rising house prices are right for households. The Liquidity Constraint Effect of Household Consumption. Hoynes and Mcdden [14] Empirical analysis using PSID data found that without a percentage point increase in house prices, the savings rate 
would rise by 0.26 percentage points. Sheiner [15] also found that rising house prices would increase the savings rate. For young people who rent in high-price cities, they would save more than those who rent in low-price cities. From the perspective of domestic research, Chen Yanbin and others [16] believe that the burden of house purchasing caused by rising house prices is an important reason for the current high savings rate of young families.

On the other hand, for low- and middle-income households who rent a house, when the house price rises to the point where they can not afford to buy a house, they may give up or delay the purchase of a house, which leads to an increase in consumption in the current period. This kind of rise in house price causes an increase in consumption, which is called the "substitution effect". Yoshikawa and Ohtaka [17] pointed out that when house prices rose, many young rental families abandoned their plans to buy houses and used the wealth they had planned to buy for current consumption. In domestic research, Du Li et al. [18] also found this substitution effect when studying the relationship between housing prices and urban residents' consumption in Shanghai.

From the existing literature, the research literature on housing price and consumption level is very rich, but the research literature on the changes of housing price and consumption structure is very few. It is worth noting that Wang Wei, Liu Zhigang and Gong Feifei use panel data of 35 large and medium-sized cities to study the impact of high housing prices on the upgrading of consumption structure. The article points out that the rise of housing price restrains the upgrading of consumption structure. For every 1 percentage point increase in house prices, the consumer structure upgrading index will fall by 0.27 percentage points. Although their research has noticed the relationship between house price and consumption structure change, it is based on the research results of macro data, and there is no systematic theoretical mechanism to sort out the impact of house price on the upgrading of consumption structure. Therefore, the relationship between house price and household consumption structure change of urban residents and the underlying mechanism need to be further demonstrated.

\section{The Mechanism of Housing Price Affecting the Change of Consumption Structure}

\subsection{The Connotation of Upgrading Consumption Structure}

At the end of the 19th century, the concept of consumption structure began to be put forward. It refers to the proportional relationship between various consumption materials consumed by consumers in a certain period of time [19]. According to the classification of consumption by the National Bureau of Statistics, consumption can be divided into food, clothing, residence, household equipment and services, health care, transportation and communication, cultural entertainment and education and others. Generally speaking, the proportion of expenditure in each category of consumption as a share of total consumption 
expenditure is regarded as the consumption structure. Engels divided the means of subsistence into subsistence, enjoyment and development, which will become one of the important classification methods to measure consumption structure in the future. The upgrading of consumption structure refers to the process in which residents' consumption structure evolves and advances from a lower standard of living to a higher quality of life, which is roughly manifested in two forms: first, the proportion of the original consumption categories remains basically unchanged, but the internal evolution of each consumption category towards a higher quality direction, such as eating healthier and greener food, using better household goods, and living better house, although the proportion of consumption categories has not changed, but the quality of life has improved. Second, with the addition of new consumption items, the ranking of different consumption categories has changed. Higher consumption categories account for a higher proportion. For example, as society pays more attention to education and spiritual enjoyment, there will be more expenditure on entertainment, so that the proportion of development and Enjoyment-oriented consumption will be higher. The former is an improved upgrading, while the latter is a revolutionary upgrading of consumption structure. In reality, there is no single upgrading of consumption structure, and these two situations often coexist. For example, we used to wear clothes, eat coarse grain, live in small courtyards, travel by bicycle, but now we pursue more fashionable clothes, eat fine grain, live in residential buildings, and drive private cars. This evolution has both improved consumption structure upgrading and revolutionary structure upgrading. The consumption structure upgrading studied in this paper mainly refers to the revolutionary consumption structure upgrading, usually leather. The upgrading of lifelong consumption structure will lead to the upgrading of improved consumption structure.

\subsection{The Influencing Mechanism of House Price Rising on the Change of Consumption Structure}

Rising house prices restrain the upgrading of consumption structure. The following three mechanisms hinder the upgrading of consumption structure: cost effect, Preventive Savings effect and liquidity constraint effect.

1) Cost effect. Rising house prices will increase the cost of family life, especially for those who have not yet bought a house, the rise of house prices will affect their consumption decisions from two aspects. On the one hand, the rise of house prices will increase the housing expenditure of rental families. In the case of a certain income, the increase of this cost will inevitably make people reduce their cultural education and payment after meeting basic living needs. Development-oriented consumption such as communication has restrained the upgrading of consumption structure. On the other hand, according to the general equilibrium theory, the rise of house prices will inevitably lead to the rise of other consumer goods prices, which further increases people's living costs, and the upgrading of consumption structure will also be affected. 
2) Preventive savings effect. As China's housing prices have remained high, this has led to the expectation that housing prices will continue to rise. This expectation will cause families with real demand for housing to worry about increasing Preventive Savings in the future with higher costs or incomes that can not keep pace with the rise in housing prices. This increase in savings will reduce the development-oriented consumption of education, training, culture, leisure and entertainment. Expenditure has slowed down the upgrading of consumption structure.

3) Liquidity constraints. High housing prices will increase the down payment of housing purchase, while loans in the credit market will increase the liquidity constraints of consumers, thus inhibiting the development and enjoyment consumption categories of residents.

Rising house prices are driving the upgrading of consumption structure. It mainly hinders the upgrading of consumption structure through the following two mechanisms: the exchange wealth effect, the non-exchange wealth effect and the substitution effect.

1) The wealth effect of exchange. For households with a house, rising house prices mean that the value of the house they hold rises. They can obtain higher household wealth by renting, selling or refinancing. The increase of household wealth will make these households turn to higher-level consumption projects when they consume.

2) The wealth effect of non-convertibility. When house prices rise, households with housing will increase their consumption projects even if they do not realize this value by selling, renting or refinancing. However, Poter (2000) pointed out that most households own housing in order to enjoy the service value provided by housing for a long time. As a whole, the effect of non-convertibility on wealth is weaker than that of convertibility on the change of household consumption structure.

3) Substitution effect. For rental households, if the house price rises so that they give up the idea of buying a house, they may use part of the income they intend to use to buy a house for consumption, thus increasing household consumption projects. This increase in consumption caused by rising house prices to a desperate level is also called "desperate consumption effect".

Through the above analysis, this paper makes the following hypothesis: house price rise promotes the upgrading of household consumption structure through the wealth effect of convertibility, the wealth effect of non-convertibility and substitution effect, and house price rise also restrains the upgrading of household consumption structure through cost effect, saving effect and liquidity constraint effect. Therefore, the impact of housing prices on household consumption structure needs further empirical verification.

\section{Data and Description of Major Variables}

\subsection{Data}

The data used in this paper are from China Family Tracking Survey Data (CFPS) 
2012 and 2014 survey databases and China Statistical Yearbook. CFPS covered 25 provinces, municipalities and districts, including 95\% of the country's population. CFPS contains rich information about family consumption, family income, housing, age of family members, education and so on, which satisfies the data needs of this study. In the process of data processing, this paper first identifies the maximum years of education for adults in the family adult database, regards the maximum years of education as the educational level of the family and generates variables, calculates the child-to-child dependency ratio and the elderly dependency ratio in the family relational database, and then matches the education level with the population dependency ratio with the family relational database, and will be from the country. The house price information collected by the Home Statistics Bureau matches the area in the family relationship database. Because the research object of this paper is urban residents, we delete the rural samples in the database and delete the missing values of the main variables. After processing the data of CFPS 2012 and CFPS 2014, we merge the two data into panel data and finally get 5241 representative samples in the whole country. Table 1 gives descriptive statistics of relevant data. From Table 1, we can see that the average proportion of family development-oriented enjoyable consumption in the sample period is $30.4 \%$, the range of change is $0-1$, the logarithmic mean value of the core explanatory variable is 8.607 , and other control variables such as education level, dependency ratio, family size have changed greatly, which meets the random requirements of variables.

\subsection{Description of Major Variables}

\subsubsection{Upgrading of Consumption Structure}

There are two main ways to measure the upgrading of consumption structure: one is Engel's coefficient method, which refers to the proportion of food consumption expenditure in total consumption expenditure. The theoretical basis of this method is Engel's law. Engel's Law means that when family income is relatively low, most of the expenditure is used for food consumption, but for health

Table 1. Descriptive statistics of relevant data.

\begin{tabular}{|c|c|c|c|c|c|c|}
\hline Variable & Variable name & Obs & Mean & Std. Dev. & Min & Max \\
\hline con struc & $\begin{array}{l}\text { Developmental Enjoyable } \\
\text { Consumption Proportion }\end{array}$ & 9303 & 0.304 & 0.186 & 0 & 1 \\
\hline $\ln H p$ & Logarithmic house prices & 10,482 & 8.607 & 0.473 & 8.100 & 9.745 \\
\hline $\max e d u$ & Family education level & 10,410 & 10.63 & 4.265 & 0 & 22 \\
\hline youngratio & Child dependency ratio & 10,482 & 0.117 & 0.153 & 0 & 1 \\
\hline oldratio & old-age dependency ratio & 10,482 & 0.170 & 0.300 & 0 & 1 \\
\hline lnFincome $\sim \mathrm{r}$ & $\begin{array}{l}\text { Logarithmic household net } \\
\text { income per capita }\end{array}$ & 10,013 & 9.273 & 1.171 & 0.191 & 15.04 \\
\hline $\ln P c e$ & $\begin{array}{l}\text { Logarithmic Total } \\
\text { Consumption Expenditure }\end{array}$ & 9303 & 10.44 & 0.851 & 6.141 & 14.24 \\
\hline f num & Family size & 10,482 & 3.553 & 1.628 & 1 & 17 \\
\hline
\end{tabular}


care, transportation, communication and entertainment education. The expenditure of development-oriented enjoyment type is less. The second is to measure the upgrading of consumption structure by increasing the proportion of expenditure on health care, culture, education, entertainment and transportation and communication. This is because with the increase of residents' income and consumption level, residents will spend more of their income on the development-oriented and enjoyable consumption of transportation, communication, medical care and entertainment education, while meeting the basic needs of clothing, food, housing and transportation. The latter is also the overwhelming majority of cultural consumption. This paper will also draw lessons from the practice of most literatures, and take the increase of the proportion of expenditure on health care, culture, education and entertainment, transportation and communication, and other goods and services in total consumption expenditure as a measure of the upgrading of consumption structure. That is, consumption structure $=($ health care + cultural, educational, entertainment + transportation and communication)/total consumption expenditure, named con_struc.

\subsubsection{Changes in House Prices}

The empirical data of this paper comes from the data of China Family Tracking Survey (CFPS 2014, CFPS 2012). Because the area of the family in this data can only be precise to the provincial level, the house price in this paper refers to the level of the house price of the family in the provincial level, and takes logarithms. The house price data of each province in 2012 and 2014 come from the average sale price of the house in China Statistical Yearbook. The CPI data are derived from China Statistical Yearbook. In addition, the CPFS survey data provide the variables of "the total market price of the existing residential house" and "the building area of your existing residential house". According to these two variables, we can estimate the house price level faced by the family. After conversion with CPI, we can get the real house price level corresponding to the family, because families with higher consumption level tend to have higher income, while families with higher income tend to buy more expensive houses, therefore, using estimated house prices to study the impact of house prices on household consumption structure may have endogenous problems. Therefore, in our empirical analysis, we still use the real housing prices at the provincial level, because the choice of household consumption items can not be considered to affect the prices of the provinces, thus avoiding endogenous problems.

\section{Model Setting and Empirical Analysis}

\subsection{Model Setting}

This article builds the following basic models

$$
\text { Con_struc }_{i p t}=\beta_{0}+\beta_{1} \ln h p_{p t}+\beta_{2} X_{i p t}+\mu_{p}+\varepsilon_{i p t}
$$

Here, Con_struc ${ }_{i p t}$ represents the proportion of household enjoyable and developmental consumption expenditure, $h p_{p t}$ represents the housing price level of 
the province in which the household is located, $X_{i p t}$ represents the control variables of household level such as per capita household net income, household population, household education level, household dependency ratio and household head characteristics, etc., $\mu_{p}$ represents the fixed effect of the province, and $\varepsilon_{i p t}$ is a random perturbation item. Here, housing price is an exogenous environmental variable at the provincial level. After controlling the fixed effect of provinces and years, we can actually use the differences of housing price growth and consumption structure changes in different provinces to identify the impact of housing prices on household consumption structure. After controlling the observable variables such as net income per capita household, family population, family education level, family dependency ratio and household head characteristics, the random perturbation term may also contain unobservable variables such as household consumption category preference, but as long as these factors are not related to the housing prices in the provinces where the households are located, we can estimate the relationship between housing prices and household consumption structure in a consistent and unbiased manner.

Regarding the control variable $X$ : Combining with the existing research literature and survey data, the control variables included in this paper are: family education level, education will affect people's consumption concept and consumption mode, and then affect consumption level and consumption structure. This paper takes the highest education level of family adults as the family education level, and the expected regression coefficient is positive. Family dependency ratio, for families with elderly people, their expenditure on health care will be relatively large, and for families with children, their expenditure on food expenditure will be relatively large; per capita net income of families, according to the law of diminishing marginal propensity to consume, per capita net income of families is negatively correlated with consumption rate, and the average per capita income level of families is higher. The proportion of consumption expenditure will be correspondingly lower; the more the total consumption expenditure of the family, the more the total consumption expenditure of the family, the more the expenditure in the category of enjoyable and developmental consumption will be, and the expected coefficient will be positive; the larger the family population size, the larger the family population size, the larger the consumption expenditure will usually be, and the impact on the upgrading of consumption structure needs to be further verified.

\subsection{Empirical Analysis}

Table 2 gives the basic regression results of model (1). Column (1) is a mixed regression result and uses the clustering robust standard error; column (2) is a fixed effect regression result; column (1) shows that the estimated coefficient of real house price is-0.0313 and very significant, indicating that the real house price rises by $10 \%$, and the proportion of family development and enjoyable consumption declines by $3 \%$; in column (2), the estimated coefficient of house 
Table 2. Basic regression.

\begin{tabular}{|c|c|c|}
\hline & (1) & (2) \\
\hline & Mixed regression & Fixed effect \\
\hline VARIABLES & con_struc & con_struc \\
\hline \multirow[t]{2}{*}{$\ln h p$} & $-0.0313^{* * *}$ & $-0.213^{\star * *}$ \\
\hline & $(0.00473)$ & $(0.0394)$ \\
\hline \multirow[t]{2}{*}{ max_edu } & $0.00409^{* * *}$ & -0.000214 \\
\hline & $(0.000600)$ & $(0.00159)$ \\
\hline \multirow[t]{2}{*}{ youngratio } & $-0.0375^{\star * *}$ & -0.000978 \\
\hline & $(0.0143)$ & $(0.0309)$ \\
\hline \multirow[t]{2}{*}{ oldratio } & $0.0187^{\star \star}$ & -0.0274 \\
\hline & $(0.00816)$ & $(0.0224)$ \\
\hline \multirow[t]{2}{*}{ lnfincome_per } & $-0.0128^{\star * \star}$ & $-0.00847^{\star * *}$ \\
\hline & $(0.00221)$ & $(0.00317)$ \\
\hline \multirow[t]{2}{*}{ lnpce } & $0.0261^{\star * *}$ & 0.00869 \\
\hline & $(0.00353)$ & $(0.00604)$ \\
\hline \multirow[t]{2}{*}{ f_num } & $0.00466^{* * *}$ & $0.0107^{\star *}$ \\
\hline & $(0.00150)$ & $(0.00465)$ \\
\hline \multirow[t]{2}{*}{ Constant } & $0.361^{* * *}$ & $2.093^{* * *}$ \\
\hline & $(0.0434)$ & $(0.327)$ \\
\hline Observations & 9052 & 9052 \\
\hline R-squared & 0.033 & 0.016 \\
\hline
\end{tabular}

price is -0.213 , which is also very significant. The results show that the rise of house prices has a significant negative impact on family development and enjoyable consumption structure, that is, the rise of house prices will inhibit the upgrading of consumption structure. The empirical results also show that household income, consumption expenditure and household population are also important factors affecting household consumption structure. The regression coefficient of household per capita net income is significantly negative, which accords with the law of diminishing marginal propensity to consume. The regression coefficient of total household consumption expenditure is significantly positive. The more total household consumption expenditure, the more development and enjoyment consumption. The coefficient of household population size is significantly positive. Usually, the larger the household population, on the one hand, the share of subsistence consumption expenditure, such as food, clothing, housing and transportation, will decrease; on the other hand, the larger the population, the greater the diversity, the greater the potential demand for development and enjoyment consumption.

\subsection{Cross-Sectional Data Analysis of the Impact of Housing Prices on Household Consumption Structure}

In order to incorporate more micro-factors that may affect the consumption 
structure of urban households into the model, and to consider more comprehensively and objectively the impact of housing price changes on the high-level consumption structure of urban households, we use the cross-sectional data of CFPS in 2014 to make an empirical analysis again. The econometric model is as follows.

$$
\text { Con_struc }_{i p}=\beta_{0}+\beta_{1} \ln h p_{p}+\beta_{2} X_{i p}+\mu_{p}+\varepsilon_{i p}
$$

Compared with the model (1), we mainly add the relevant characteristic variables of family financial respondents to the control variables, and the heterogeneous factors that may affect our research.

Using Stata 13.0 software, we first estimate the model (2) by distinguishing the households with housing from those with rental housing. The households with rental housing include low-rent housing, public rental housing and commercial housing on the market. The estimated results are shown in Table 3. Among them, the first column is the regression result of the housing family, the third column is the regression result of the rental family, and the fourth, fifth and sixth columns are the regression result of the subdivision of the rental family. From the regression result of the first column, for the household with a house, the rising house price will not crowd in the enjoyable development expenditure of the household, on the contrary, it will be beneficial to the upgrading of the household consumption structure. The regression coefficient of house price is not significant, but for rental families, the rise of house price will significantly inhibit the upgrading of household consumption structure. This may be because households with houses have less pressure on rent when facing the rise of house price than households with rental houses, while households with rental houses have to face not only the pressure of rent increase, but also the pressure of buying houses, thus reducing spending of High-level consume. In the sub-sample of rental households, we find that the rise of house prices has the greatest impact on the consumption structure of families renting commercial housing in the market, followed by public rental housing, and low-rent housing has the smallest impact.

For the households with housing, if only one set of housing is used for self-living, then the rise of housing prices may have little impact on the consumption structure. At present, China's housing financial market is still imperfect, there is no housing refinancing business, households with housing can not use the value-added housing wealth to apply for additional mortgage loans. Therefore, families with only one set of housing can not use value-added housing wealth for more development-oriented consumption when house prices rise. However, if a family owns more than one house, the increase of housing wealth will be caused by the rise of housing prices, which can be realized by selling and renting, so that more income can be used for the development of enjoyable consumption projects, that is, families with more than one house, the wealth effect of rising housing prices will be greater. In order to verify the effect of wealth effect, we are introducing "whether or not". The dummy variable of "owning more 
Table 3. Expanded regression (sub-sample regression).

\begin{tabular}{|c|c|c|c|c|c|c|}
\hline & (1) & (2) & (3) & (4) & (5) & (6) \\
\hline & $\begin{array}{c}\text { Family with } \\
\text { housing }\end{array}$ & $\begin{array}{l}\text { Family with } \\
\text { housing }\end{array}$ & $\begin{array}{l}\text { Renting } \\
\text { family }\end{array}$ & $\begin{array}{l}\text { Low rent } \\
\text { housing }\end{array}$ & $\begin{array}{l}\text { Public Rental } \\
\text { Housing }\end{array}$ & $\begin{array}{c}\text { Commercial } \\
\text { housing }\end{array}$ \\
\hline VARIABLES & con_struc & con_struc & con_struc & con_struc & con_struc & con_struc \\
\hline \multirow[t]{2}{*}{$\ln h p$} & 0.00595 & -0.00398 & $-0.193^{\star * *}$ & $-0.133^{\star *}$ & $-0.193^{\star * *}$ & $-0.284^{\star * *}$ \\
\hline & $(0.0209)$ & $(0.0219)$ & $(0.0172)$ & $(0.0508)$ & $(0.0322)$ & $(0.0236)$ \\
\hline \multirow[t]{2}{*}{ max_edu } & $0.00230^{* * *}$ & $0.00231^{\star * \star}$ & -0.000557 & 0.000867 & $-0.00816^{*}$ & 0.00241 \\
\hline & $(0.000827)$ & $(0.000827)$ & $(0.00188)$ & $(0.00358)$ & $(0.00478)$ & $(0.00235)$ \\
\hline \multirow[t]{2}{*}{ youngratio } & $-0.0469^{* *}$ & $-0.0468^{\star \star}$ & -0.0628 & 0.0303 & -0.133 & -0.0621 \\
\hline & $(0.0198)$ & $(0.0198)$ & $(0.0434)$ & $(0.0977)$ & $(0.134)$ & $(0.0539)$ \\
\hline \multirow[t]{2}{*}{ oldratio } & $0.0220^{*}$ & $0.0224^{*}$ & 0.0195 & 0.000459 & 0.00929 & 0.0546 \\
\hline & $(0.0129)$ & $(0.0129)$ & $(0.0453)$ & $(0.117)$ & $(0.0707)$ & $(0.0738)$ \\
\hline \multirow[t]{2}{*}{ lnfincome_per } & $-0.0130^{\star * *}$ & $-0.0130^{\star * *}$ & -0.0100 & -0.0183 & -0.00710 & -0.00786 \\
\hline & $(0.00307)$ & $(0.00307)$ & $(0.00744)$ & $(0.0140)$ & $(0.0184)$ & $(0.00903)$ \\
\hline \multirow[t]{2}{*}{ lnpce } & $0.0181^{* * *}$ & $0.0181^{* * *}$ & $0.0339^{* * *}$ & 0.0109 & $0.0603^{* *}$ & 0.0243 \\
\hline & $(0.00468)$ & $(0.00473)$ & $(0.0127)$ & $(0.0274)$ & $(0.0300)$ & $(0.0162)$ \\
\hline \multirow[t]{2}{*}{ f_num } & $0.00933^{* * *}$ & $0.00924^{\star * *}$ & $0.0111^{*}$ & 0.0192 & 0.0197 & 0.00573 \\
\hline & $(0.00200)$ & $(0.00201)$ & $(0.00585)$ & $(0.0131)$ & $(0.0137)$ & $(0.00754)$ \\
\hline \multirow[t]{2}{*}{ age } & 0.000131 & 0.000145 & -0.00418 & -0.00383 & -0.00677 & 0.000428 \\
\hline & $(0.00108)$ & $(0.00108)$ & $(0.00322)$ & $(0.00607)$ & $(0.00625)$ & $(0.00485)$ \\
\hline \multirow[t]{2}{*}{ lnAge } & -0.00315 & -0.00285 & $0.104^{*}$ & 0.0594 & 0.133 & 0.0410 \\
\hline & $(0.0232)$ & $(0.0233)$ & $(0.0594)$ & $(0.118)$ & $(0.108)$ & $(0.0892)$ \\
\hline \multirow[t]{2}{*}{$\operatorname{sex}$} & $-0.0122^{* *}$ & $-0.0126^{* *}$ & -0.0187 & -0.0120 & -0.0209 & -0.0266 \\
\hline & $(0.00532)$ & $(0.00531)$ & $(0.0132)$ & $(0.0275)$ & $(0.0372)$ & $(0.0171)$ \\
\hline \multirow[t]{2}{*}{ morehouse } & & $-0.297^{* *}$ & & & & \\
\hline & & $(0.120)$ & & & & \\
\hline \multirow[t]{2}{*}{$\begin{array}{c}\text { morehouse } \times \\
\ln h p\end{array}$} & & $0.0342^{\star *}$ & & & & \\
\hline & & $(0.0137)$ & & & & \\
\hline \multirow[t]{2}{*}{ Constant } & 0.146 & 0.227 & $1.262^{\star \star \star}$ & 1.220 & 0.903 & $2.525^{\star \star \star}$ \\
\hline & $(0.224)$ & $(0.230)$ & $(0.308)$ & $(0.807)$ & $(0.686)$ & $(0.534)$ \\
\hline Observations & 4485 & 4485 & 558 & 123 & 135 & 300 \\
\hline R-squared & 0.042 & 0.043 & 0.138 & 0.359 & 0.227 & 0.232 \\
\hline
\end{tabular}

Note: 1$)^{*}$ means $P<0.1 ;{ }^{* *}$ means $P<0.05$; ${ }^{* *}$ means $\left.P<0.01 ; 2\right)$ standard errors in parentheses; 3 ) all regional effects have been controlled.

than one house" and its interaction with house price are listed in the third (3) table. The results show that the rise of house price is negatively correlated with the upgrading of household consumption structure, but it is not significant. The 
regression coefficient of the interaction between housing prices and multiple housing units is significantly positive, that is to say, the households with multiple housing units will significantly increase the proportion of development-oriented enjoyable consumption expenditure when housing prices rise, which indicates that there is a significant "convertible wealth" effect in the households with multiple housing units when housing prices rise in China.

The change of housing status, especially the change of family from renting to housing, is often the result of family self-selection. In the regression results of Table 3, the self-selection of family housing status is not taken into account. Especially for rental households, the housing status may change in 2014. If families with higher income or higher proportion of developmental consumption choose to buy a house in 2013-2014, the foregoing estimates may have sample selection bias. Fortunately, the CFPS data counts the time spent on home purchases, which helps us to identify changes in household housing status. We excluded the households that purchased the first house in CFPS in 2014 from the households with houses in 2013-2014 and classified them as rental households, thus reducing the number of households with houses by 219 and increasing the number of households with houses by 219 . Then, the adjusted data are used to re-estimate, and the regression results are shown in Table 4 . The results in Table 4 are basically similar to those in Table 3. However, the restraining effect of rising house prices on the upgrading of the consumption structure of rental households is weakened, and the basic conclusion remains unchanged.

Table 4. Expanded regression (considering sample selection).

\begin{tabular}{|c|c|c|c|}
\hline & (1) & (2) & (3) \\
\hline & Family with housing & Family with housing & Renting family \\
\hline VARIABLES & con_struc & con_struc & con_struc \\
\hline \multirow[t]{2}{*}{$\ln h p$} & 0.00105 & -0.00869 & $-0.168^{\star * *}$ \\
\hline & $(0.0210)$ & $(0.0219)$ & $(0.0180)$ \\
\hline \multirow[t]{2}{*}{ max_edu } & $0.00162^{*}$ & $0.00164^{*}$ & $0.00324^{*}$ \\
\hline & $(0.000849)$ & $(0.000848)$ & $(0.00168)$ \\
\hline \multirow[t]{2}{*}{ youngratio } & $-0.0487^{\star \star}$ & $-0.0484^{\star \star}$ & -0.00936 \\
\hline & $(0.0202)$ & $(0.0202)$ & $(0.0385)$ \\
\hline \multirow[t]{2}{*}{ oldratio } & 0.0182 & 0.0188 & 0.0521 \\
\hline & $(0.0131)$ & $(0.0131)$ & $(0.0367)$ \\
\hline \multirow[t]{2}{*}{ lnfincome_per } & $-0.0147^{\star \star \star}$ & $-0.0147^{\star * *}$ & -0.00444 \\
\hline & $(0.00317)$ & $(0.00317)$ & $(0.00594)$ \\
\hline \multirow[t]{2}{*}{ lnpce } & $0.0274^{\star \star \star}$ & $0.0275^{\star \star \star}$ & -0.0128 \\
\hline & $(0.00490)$ & $(0.00493)$ & $(0.00866)$ \\
\hline \multirow[t]{2}{*}{ f_num } & $0.00818^{* * *}$ & $0.00811^{\star * *}$ & $0.0111^{\star *}$ \\
\hline & $(0.00204)$ & $(0.00205)$ & $(0.00470)$ \\
\hline
\end{tabular}




\begin{tabular}{cccc} 
Continued & & & \\
\hline age & 0.000420 & 0.000421 & $-0.00654^{* *}$ \\
& $(0.00109)$ & $(0.00110)$ & $(0.00257)$ \\
lnAge & -0.00965 & -0.00905 & $0.144^{* * *}$ \\
sex & $(0.0236)$ & $(0.0237)$ & $(0.0498)$ \\
& $-0.0116^{* *}$ & $-0.0119^{* *}$ & $-0.0199^{*}$ \\
morehouse & $(0.00541)$ & $(0.00541)$ & $(0.0116)$ \\
& & $-0.283^{* *}$ & \\
morehouse $\times h p$ & & $(0.122)$ & \\
& & $0.0325^{* *}$ & \\
Constant & & $(0.0139)$ & $1.236^{* * *}$ \\
& 0.151 & 0.228 & $(0.272)$ \\
Observations & $(0.226)$ & $(0.232)$ & 739 \\
R-squared & 4304 & 4304 & 0.105 \\
\hline
\end{tabular}

Note: 1$)^{*}$ means $P<0.1$; ${ }^{* *}$ means $P<0.05$; ${ }^{* *}$ means $\left.P<0.01 ; 2\right)$ standard errors in parentheses; 3$)$ all regional effects have been controlled.

So far, our empirical results show that rising house prices will restrain the upgrading of household consumption structure, but rising house prices mainly affect the upgrading of household consumption structure of rental families, which is not significant for households with housing, but there is a greater "wealth effect" in the face of rising house prices for households with multiple housing units, which will make households turn to higher levels of consumption.

\section{Robustness Test}

\subsection{Heterogeneity of Family Income}

The empirical results show that the impact of housing prices on the upgrading of urban household consumption structure is negative. But if we study the impact of housing prices on the upgrading of household consumption structure in a general way with homogeneous "representative families", we may fall into the trap of "average effect". In view of this, considering that households with different income levels may have different consumption structures, this paper then introduces the heterogeneity of household income by differentiating household income status, in order to further study the impact of housing prices on the upgrading of household consumption structure under different income levels. In order to distinguish the impact of housing prices on the upgrading of household consumption structure under different income conditions, this paper divides three sub-samples according to household income conditions, namely, household samples above the median, household samples below the median and middle-income household samples. Table 5 shows the regression results of the sub-samples. The results show that for low-income families, there is no inhibitory 
Table 5. Heterogeneity of family income.

\begin{tabular}{|c|c|c|c|}
\hline & (1) & (2) & (3) \\
\hline & $\begin{array}{l}\text { Family samples below } \\
\text { median }\end{array}$ & $\begin{array}{c}\text { Sample of middle-income } \\
\text { households }\end{array}$ & $\begin{array}{c}\text { Family samples above } \\
\text { median }\end{array}$ \\
\hline VARIABLES & con_struc & con_struc & con_struc \\
\hline \multirow[t]{2}{*}{$\ln h p$} & 0.151 & $-0.212^{\star \star \star}$ & $-0.250^{* * *}$ \\
\hline & $(0.190)$ & $(0.0753)$ & $(0.0728)$ \\
\hline \multirow[t]{2}{*}{ max_edu } & 0.000661 & 0.000780 & 0.00346 \\
\hline & $(0.00595)$ & $(0.00296)$ & $(0.00383)$ \\
\hline \multirow[t]{2}{*}{ youngratio } & 0.111 & 0.0162 & -0.0114 \\
\hline & $(0.167)$ & $(0.0504)$ & $(0.0656)$ \\
\hline \multirow[t]{2}{*}{ oldratio } & $-0.188^{\star \star}$ & 0.0217 & -0.0104 \\
\hline & $(0.0802)$ & $(0.0455)$ & $(0.0354)$ \\
\hline \multirow[t]{2}{*}{ lnfincome_per } & 0.0122 & -0.0156 & -0.0134 \\
\hline & $(0.0136)$ & $(0.0144)$ & $(0.0111)$ \\
\hline \multirow[t]{2}{*}{ lnpce } & $0.0529^{* *}$ & -0.0111 & -0.0168 \\
\hline & $(0.0268)$ & $(0.0117)$ & $(0.0113)$ \\
\hline \multirow[t]{2}{*}{ f_num } & -0.00216 & 0.00999 & 0.00659 \\
\hline & $(0.0228)$ & $(0.00900)$ & $(0.0105)$ \\
\hline \multirow[t]{2}{*}{ Constant } & -1.540 & $2.316^{* * *}$ & $2.746^{\star * *}$ \\
\hline & $(1.614)$ & $(0.627)$ & $(0.611)$ \\
\hline Observations & 1413 & 4119 & 3520 \\
\hline R-squared & 0.054 & 0.015 & 0.027 \\
\hline
\end{tabular}

Note: 1$){ }^{*}$ means $P<0.1$; ${ }^{* *}$ means $P<0.05$; ${ }^{* * *}$ means $P<0.01$; 2 standard errors in parentheses; 3 ) all regional effects have been controlled.

effect of rising house prices on the upgrading of household consumption structure, but for middle and high-income families, house prices are significantly negatively correlated with the upgrading of household consumption structure. The reason for this difference may be that, for low-income families, when house prices rise, they will abandon the purchase plan and use this part of the income to purchase for consumption, that is, low-income families have greater substitution effect in the face of rising house prices.

\subsection{Quantile Regression}

This section examines the impact of housing price changes on household consumption structure of urban residents in different consumption structure levels. Families with a high proportion of high-level consumption structure tend to be those with higher incomes. Under the background of rising house prices, they may face less pressure. Therefore, the restraint effect of rising house prices on their consumption structure upgrading may not be significant. Table 6 shows 
Table 6. Quantile regression.

\begin{tabular}{|c|c|c|c|c|c|c|c|c|c|}
\hline & (1) & (2) & (3) & $(4)$ & (5) & (6) & (7) & (8) & (9) \\
\hline & 0.1 & 0.2 & 0.3 & 0.4 & 0.5 & 0.6 & 0.7 & 0.8 & 0.9 \\
\hline VARIABLES & con_struc & con_struc & con_struc & con_struc & con_struc & con_struc & con_struc & con_struc & con_struc \\
\hline \multirow[t]{2}{*}{$\ln h p$} & 0.000812 & $-0.00752^{\star}$ & $-0.0150^{* * *}$ & $-0.0202^{* * *}$ & $-0.0313^{* * *}$ & $-0.0405^{\star * *}$ & $-0.0485^{\star * *}$ & $-0.0507^{\star * *}$ & $-0.0683^{* * *}$ \\
\hline & $(0.00356)$ & $(0.00428)$ & $(0.00478)$ & $(0.00510)$ & $(0.00567)$ & $(0.00664)$ & $(0.00733)$ & $(0.00774)$ & $(0.00962)$ \\
\hline \multirow[t]{2}{*}{ max_edu } & $0.00394^{* * *}$ & $0.00503^{* * *}$ & $0.00525^{\star * *}$ & $0.00597^{\star * *}$ & $0.00548^{\star * *}$ & $0.00499^{* * *}$ & $0.00496^{\star * *}$ & $0.00282^{\star * *}$ & 0.00160 \\
\hline & $(0.000434)$ & $(0.000522)$ & $(0.000583)$ & $(0.000622)$ & $(0.000692)$ & $(0.000810)$ & $(0.000894)$ & $(0.000944)$ & $(0.00117)$ \\
\hline \multirow[t]{2}{*}{ youngratio } & $0.0445^{\star * *}$ & $0.0576^{\star \star *}$ & $0.0417^{\star \star *}$ & $0.0340^{\star \star}$ & -0.0176 & -0.0341 & $-0.0761^{\star \star \star}$ & $-0.110^{* * *}$ & $-0.181^{\star \star \star}$ \\
\hline & $(0.0115)$ & $(0.0139)$ & $(0.0155)$ & $(0.0165)$ & $(0.0184)$ & $(0.0215)$ & $(0.0237)$ & $(0.0251)$ & $(0.0311)$ \\
\hline \multirow[t]{2}{*}{ oldratio } & $-0.0111^{\star}$ & -0.00332 & 0.00356 & 0.00807 & 0.0128 & $0.0179^{*}$ & $0.0223^{*}$ & $0.0419^{\star * \star}$ & $0.0545^{\star * *}$ \\
\hline & $(0.00574)$ & $(0.00691)$ & $(0.00773)$ & $(0.00823)$ & $(0.00916)$ & $(0.0107)$ & $(0.0118)$ & $(0.0125)$ & $(0.0155)$ \\
\hline \multirow[t]{2}{*}{ lnfincome_per } & -0.00129 & -0.000764 & -0.000162 & -0.00369 & $-0.00931^{\star * *}$ & $-0.0132^{\star * *}$ & $-0.0195^{\star \star \star}$ & $-0.0261^{\star * *}$ & $-0.0370^{* * *}$ \\
\hline & $(0.00158)$ & $(0.00190)$ & $(0.00212)$ & $(0.00226)$ & $(0.00252)$ & $(0.00295)$ & $(0.00326)$ & $(0.00344)$ & $(0.00427)$ \\
\hline \multirow[t]{2}{*}{ lnpce } & -0.00357 & -0.00153 & 0.00321 & $0.0121^{\star * \star}$ & $0.0285^{\star * *}$ & $0.0400^{\star * *}$ & $0.0458^{\star * *}$ & $0.0551^{\star \star *}$ & $0.0696^{* * *}$ \\
\hline & $(0.00224)$ & $(0.00270)$ & $(0.00302)$ & $(0.00322)$ & $(0.00358)$ & $(0.00419)$ & $(0.00463)$ & $(0.00489)$ & $(0.00607)$ \\
\hline \multirow[t]{2}{*}{ f_num } & $0.00599^{* * *}$ & $0.00773^{\star \star \star}$ & $0.00883^{* * *}$ & $0.00785^{\star * *}$ & $0.00474^{\star \star}$ & $0.00439^{\star *}$ & $0.00478^{\star \star}$ & 0.00255 & -0.000916 \\
\hline & $(0.00116)$ & $(0.00139)$ & $(0.00155)$ & $(0.00166)$ & $(0.00184)$ & $(0.00216)$ & $(0.00238)$ & $(0.00252)$ & $(0.00313)$ \\
\hline \multirow[t]{2}{*}{ Constant } & $0.0723^{\star \star}$ & $0.142^{\star \star *}$ & $0.188^{\star \star *}$ & $0.210^{\star * *}$ & $0.255^{\star \star *}$ & $0.309^{* * *}$ & $0.438^{\star * *}$ & $0.525^{\star * *}$ & $0.765^{\star * *}$ \\
\hline & $(0.0317)$ & $(0.0382)$ & $(0.0427)$ & $(0.0455)$ & $(0.0506)$ & $(0.0593)$ & $(0.0654)$ & $(0.0691)$ & $(0.0858)$ \\
\hline Observations & 9052 & 9052 & 9,052 & 9052 & 9052 & 9052 & 9052 & 9052 & 9052 \\
\hline
\end{tabular}

Note: 1$)^{\star}$ means $P<0.1$; ${ }^{* *}$ means $P<0.05$; ${ }^{* * *}$ means $\left.P<0.01 ; 2\right)$ standard errors in parentheses; 3 ) all regional effects have been controlled.

that in different consumption structure levels, the rise of house price has a negative impact on the upgrading of household consumption structure of urban residents. The negative impact of the rise of house price above 0.2 quantile on the upgrading of household consumption structure is significant, and the lower the consumption structure level, the greater the negative impact of the rise of house price on the upgrading of household consumption structure. Therefore, quantile estimates show that rising house prices will inhibit the upgrading of household consumption structure of urban residents.

\section{Model Expansion: Regional Differences}

In order to obtain more accurate and detailed estimation results, this section will examine the impact of housing price changes on household consumption structure of urban residents in different regions. We divide the sample into three sub-samples: Eastern region, central region and Western region (Table 7). 
Table 7. Extension of the model: regional differences.

\begin{tabular}{|c|c|c|c|}
\hline & (1) & (2) & (3) \\
\hline & Eastern Region & Central region & Western Region \\
\hline VARIABLES & con_struc & con_struc & con_struc \\
\hline \multirow[t]{2}{*}{$\ln h p$} & $-0.239^{* * *}$ & $-0.236^{\star * *}$ & -0.116 \\
\hline & $(0.0608)$ & $(0.0656)$ & $(0.0903)$ \\
\hline \multirow[t]{2}{*}{ max_edu } & -0.000164 & -0.00114 & 0.00282 \\
\hline & $(0.00218)$ & $(0.00293)$ & $(0.00372)$ \\
\hline \multirow[t]{2}{*}{ youngratio } & -0.000255 & 0.0149 & -0.00432 \\
\hline & $(0.0456)$ & $(0.0487)$ & $(0.0779)$ \\
\hline \multirow[t]{2}{*}{ oldratio } & -0.0421 & -0.0210 & 0.0253 \\
\hline & $(0.0310)$ & $(0.0395)$ & $(0.0538)$ \\
\hline \multirow[t]{2}{*}{ lnfincome_per } & -0.00615 & $-0.0105^{\star *}$ & -0.00630 \\
\hline & $(0.00494)$ & $(0.00522)$ & $(0.00661)$ \\
\hline \multirow[t]{2}{*}{ lnpce } & $0.0206^{* *}$ & 0.0168 & $-0.0322^{* *}$ \\
\hline & $(0.00867)$ & $(0.0103)$ & $(0.0139)$ \\
\hline \multirow[t]{2}{*}{ f_num } & 0.00893 & $0.0165^{*}$ & $1.22 \mathrm{e}-05$ \\
\hline & $(0.00621)$ & $(0.00886)$ & $(0.00970)$ \\
\hline \multirow[t]{2}{*}{ Constant } & $2.245^{\star * *}$ & $2.146^{* * *}$ & $1.627^{\star *}$ \\
\hline & $(0.522)$ & $(0.516)$ & $(0.749)$ \\
\hline Observations & 4606 & 2909 & 1536 \\
\hline R-squared & 0.022 & 0.024 & 0.023 \\
\hline
\end{tabular}

Note: 1$)^{*}$ means $P<0.1$; ${ }^{* *}$ means $P<0.05$; ${ }^{* *}$ means $\left.P<0.01 ; 2\right)$ standard errors in parentheses; 3 ) all regional effects have been controlled.

\section{Conclusions and Enlightenment}

Through theoretical analysis and sorting, this paper explores the impact of rising house prices on the upgrading of household consumption structure of urban residents. The main conclusions are as follows: Firstly, rising house prices have a negative impact on the proportion of development-oriented and enjoyable consumption expenditure, while rising house prices have a significant inhibitory effect on the upgrading of urban household consumption structure, that is, rising house prices are not conducive to the upgrading of consumption structure. Secondly, after differentiating the sample of households with and without rental housing, we find that the rise of house price mainly inhibits the upgrading of household consumption structure. For families with multiple housing units, the rise of house price is beneficial to the upgrading of household consumption 
structure. The main reason is that households with multiple housing units will have larger wealth effect when the house price rises. Thirdly, further investigation shows that, in terms of regional differences, the negative effect of rising house prices on consumption structure is more obvious in the eastern and central regions.

Under the background of the rising house prices and the slow upgrading of household consumption structure of urban residents in China, combined with the conclusions of this study, we can draw the following enlightenments: 1) starting from the supply-side structural reform ${ }^{2}$, we should increase the supply of land area and control the irrational rise of house prices in order to prevent the negative impact of excessive rising house prices on the upgrading of consumption structure; 2) the government should focus on improving the housing security policy to alleviate the pressure of rental families in the face of rising house prices, enhance their sense of well-being, and thus improve the consumption structure of these families; 3 ) improve the financial system reform, develop consumer credit products, promote consumption upgrading, and shift to the economic development mode driven by domestic demand. In addition, this paper also has some shortcomings: 1) The price used in this paper is the housing price of the province where the residents live, not the data of the city where the residents live. 2) Because we use micro data, there are many factors affecting a household's consumption decision-making. There are some important factors, but we have not found a good measure, such as consumption preference, neighborhood comparison and so on.

\section{Conflicts of Interest}

The author declares no conflicts of interest regarding the publication of this paper.

\section{References}

[1] Xie, J.Y., Wu, B.Z., Li, H.B. and Zheng, S.Q. (2012) Urban Housing Prices and Resident Consumption in China. Financial Research, No. 6, 13-27.

[2] Li, C.D. and Huang, Y.Y. (2015) Rising House Prices, Multi-Apartment Decision-Making and Savings Rate of Urban Residents in China. Economic Research, 50, 100-113.

[3] Du, L. and Luo, J.L. (2017) How Does Rising House Prices Affect the Consumption Propensity of Urban Residents in China: A Study Based on Two-Stage Family Optimal Consumption Model. Finance and Trade Economy, 38, 67-82.

[4] Zhao, X.L., Liang, W.Q., Li, S. (2014) Can Rising House Prices Explain the High Savings Rate of Urban Residents in China?-Empirical Analysis Based on CHIP Micro-Data. Economics (Quarterly), 13, 81-102.

[5] Ando, A. and Modigliani, F. (1963) The "Life Cycle" Hypothesis of Saving: Aggre-

${ }^{2}$ The purpose of supply-side structural reform is to adjust the economic structure, optimize the allocation of factors and improve the quality and quantity of economic growth. Demand-side reform includes investment, consumption and export, while supply-side reform includes labor, land, capital, system creation and innovation. 
gate Implications and Tests. American Economic Review, 53, 55-84.

[6] Gan, J. (2010) Housing Wealth and Consumption Growth: Evidence from a Large Panel of Households. The Review of Financial Studies, 23, 2229-2267. https://doi.org/10.1093/rfs/hhp127

[7] Benjamin, J.D., Chinloy, P. and Jud, G.D. (2004) Real Estate versus Financial Wealth in Consumption. The Journal of Real Estate Finance and Economics, 29, 341-354. https://doi.org/10.1023/B:REAL.0000036677.42950.98

[8] Lusting, H.N. and Nieuwerburgh, S.G. (2005) Housing Collateral, Consumption Insurance, and Risk Premia: An Empirical Perspective. The Journal of Finance, 60, 1167-1219. https://doi.org/10.1111/j.1540-6261.2005.00759.x

[9] Munnell, A.H. and Soto, M. (2008) The Housing Bubble and Retirement Security. CRR Working Paper No. 2008-13. https://doi.org/10.2139/ssrn.1360878

[10] Chen, J., Chen, J. and Gao, B. (2012) Research on Credit Constraints, Housing Prices and Resident Consumption Rate u Based on Panel Threshold Model. Financial Research, No. 4, 45-57.

[11] Campbell, J.Y. and Cocco, J.F. (2007) How Do House Price Affect Consumption? Evidence from Micro Data. Journal of Monetary Economics, 54, 591-621. https://doi.org/10.1016/j.jmoneco.2005.10.016

[12] Skinner, J. (1996) Is Housing Wealth and Aggregate Saving. Regional Science and Urban Economics, 19, 305-324. https://doi.org/10.1016/0166-0462(89)90008-2

[13] Lehnert, A. (2004) Housing, Consumption, and Credit Constraints. FEDS Working Paper, No. 2004-63. https://doi.org/10.2139/ssrn.633261

[14] Hoynes, H. and McFadden, D. (1994) The Impact on Demographics on Housing and Non-Housing Wealth in the United States. NBER Working Paper 4666. https://doi.org/10.3386/w4666

[15] Sheiner, L. (1995) Housing Prices and the Savings of Renters. Journal of Urban Economics, 38, 94-125.

[16] Chen, Y.B. and Qiu, Z.S. (2011) How High House Prices Affect Residents' Savings Rate and Property Inequality. Economic Research, 46, 25-38.

[17] Yoshikawa, H. and Ohtaka, F. (1989) An Analysis of Female Labor Supply, Housing Demand and the Saving Rate in Japan. European Economic Review, 33, 997-1023. https://doi.org/10.1016/0014-2921(89)90010-X

[18] Du, L., Shen, J.G. and Pan, C.Y. (2013) Empirical Research on the Impact of Rising House Prices on the Average Consumption Tendency of Urban Residents uu Based on the Data of Shanghai Household Survey. Financial Research, No. 3, 44-57.

[19] Tian, H. (2013) Consumption. Economics. Tongji University Press, Shanghai. 